\title{
Effect of methyl jasmonate treatments on the bioactive compounds and physicochemical quality of 'Fuji' apples
}

\author{
Burhan Öztürk, Ebubekir Altuntas, Kenan Yildiz, Yakup Ozkan, and Onur \\ Saracoglu \\ Faculty of Agriculture, University of Gaziosmanpasa. 60240 Tasliciftlik, Tokat, Turkey.
}

\begin{abstract}
B. Ozturk, E. Altuntas, K. Yildiz, Y. Ozkan, and O. Saracoglu. 2013. Effect of methyl jasmonate treatments on the bioactive compounds and physicochemical quality of ' $F u j i$ ' apples. Cien. Inv. Agr. 40(1):201-211. Recently, plant growth regulators have been used for various purposes in apples. Methyl jasmonate (MeJA) has significant effects on the physiology, postharvest biology, processing, and chemical composition of apples. In the present study, the effects of MeJAMeJa treatments on the physicochemical quality and bioactive compounds (total antioxidant activity, total phenolics, and total anthocyanins) of 'Fuji' apples were investigated. The following doses of MeJa were used: 0 (control); 1; 120; 2,240; and 4,480 $\mathrm{mg} \mathrm{L}^{-1}$. The highest geometric mean diameter, fruit mass, flesh firmness and skin thickness were obtained from the $2,240 \mathrm{mg} \mathrm{L}^{-1}$ MeJA treatment. Fruits harvested from control trees exhibited the highest total soluble solids content (TSSC) and $\mathrm{pH}$, whereas the lowest TSSC and $\mathrm{pH}$ values were obtained from the $4,480 \mathrm{mg} \mathrm{L}^{-1} \mathrm{MeJA}$ treatment. The titratable acidity was lower in the control as compared to the other treatments. The total phenolics of the fruit flesh decreased with increasing MeJa doses. The highest total antioxidant activity for both the FRAP and TEAC of fruit flesh was obtained from the $1,120 \mathrm{mg} \mathrm{L}^{-1} \mathrm{MeJA}$ dose. The total anthocyanin content was higher in the $4,480 \mathrm{mg} \mathrm{L}^{-1} \mathrm{MeJA}$ treatment than in the other treatments. Hue angles for both the sun- and shade-exposed sides of the fruit skin and flesh were lower in the $4,480 \mathrm{mg} \mathrm{L}^{-1} \mathrm{MeJA}$ treatment as compared to the other treatments. Apples without full color formation are sold at lower prices in markets, which results in significant economic losses for producers. MeJA may be used as an efficient treatment to promote color formation in apple species with weak coloring due to genetic and climate conditions.
\end{abstract}

Key words: Apple, antioxidant, color, firmness, methyl jasmonate, phenolics.

\section{Introduction}

Apples are a rich source of various biochemical compounds, such as anthocyanin, antioxidant and phenolic compounds (Rohwer and Erwin, 2008).

Received February 3, 2012. Accepted August 18, 2012. Corresponding author: burhanozturk55@gmail.com
Some phytochemicals, including phenolics and antioxidants in fruit, consumed as a part of diet may have health benefits toward treating diabetes, obesity, muscle damage, cardiovascular disease, and asthma (Jakopic et al., 2009). Because of the health benefits attributed to various fruits, numerous studies have been conducted in recent years to evaluate their properties in terms of quality and biochemistry (Gonzalez-Gomez et al., 2009). 
The knowledge of the biochemical compounds, color characteristics and physical properties of apple fruits is of importance to plant breeders, engineers, food scientists, processors, and consumers. In recent years, the use of eco-friendly natural plant growth regulators has targeted the improvement and protection of fruit quality. Pre-harvest and post-harvest applications of some plant growth regulators in fresh fruit and vegetables are new approaches that are effective in maintaining the quality of products.

Methyl jasmonate (MeJa) is widely used both experimentally and commercially for different fruits. MeJA is among the factors that can cause changes in the physical appearance (color and fruit mass), mechanical property (firmness), and bioactive compounds (phenolics and antioxidants) of fruit (Fan et al., 1997; 1998; Kondo et al., 2001; Rudell et al., 2005; Wang and Zheng, 2005; Rohwer and Erwin, 2008). MeJa is an important cellular regulator that is involved in diverse developmental stages, such as fruit ripening, synthesis of ethylene, and accumulation of pigments, phenolics, antioxidants, and flavonoids (Cheong and Choi, 2003; Rohwer and Erwin, 2008; Heridia and Cisneros-Zevallos, 2009).

Researchers have conducted studies to investigate the effects of jasmonates on the biochemical and color properties of apple cultivars (Fan et al., 1997; Rudell and Mattheis, 2008). However, studies on the effects of different MeJa doses on the total antioxidant activity, total phenolics, total anthocyanins and color characteristics of 'Fuji' apples are lacking. Therefore, the objective of this study was to investigate the effects of preharvest MeJa treatments on the physicochemical quality (geometric mean diameter, fruit mass, flesh firmness, skin firmness, skin thickness, color characteristics, TSSC, $\mathrm{pH}$, titratable acidity and starch index), total antioxidant activity, total phenolics and total anthocyanins of 'Fuji' apples.

\section{Materials and methods}

\section{Experimental site}

This study was conducted at the Research Station of the Agricultural Faculty Horticulture Department of Gaziosmanpaşa University (40²0'02.19” N and 36'28'30.11" E; 623 masl) in Tokat, Turkey. Twenty-four uniform 4-year-old 'Fuji' (Malus domestica Borkh.) trees grafted on M9 rootstock, trained by a slender spindle training system, and planted with a spacing of $2 \mathrm{~m} \times 1 \mathrm{~m}$ were selected for the experiment.

\section{Treatment design and management}

The experimental design was a completely randomized block design with three blocks containing eight trees each. Each MeJA dose was applied to two trees in each block, and two trees in each block were selected for the control treatment (0 $\left.\mathrm{mg} \mathrm{L}^{-1} \mathrm{MeJA}\right)$. The following treatments were used in the present study: $0 \mathrm{mg} \mathrm{L}^{-1}$ (MeJA- 0 control); 1,120 $\mathrm{mg} \mathrm{L}^{-1}$ (MeJA-1); 2,240 mg L ${ }^{-1}$ (MeJA-2); and 4,480 $\mathrm{mg} \mathrm{L}^{-1}$ (MeJA-3). The MeJA doses were selected based on previous preliminary studies (Rudell et al., 2002; 2005) performed under field conditions. The MeJA doses were applied to the fruit every week using hand-operated pump spray bottles. The MeJA doses (Aldrich, Milwaukee, Wis.) were applied weekly from September 23, 2010, to October 21, 2010. All spray solutions contained $0.077 \% \mathrm{v} / \mathrm{v}$ Triton X-100 (octoxynol; Aldrich). Only Triton X-100 was applied to the control trees. Each fruit was sprayed until the solution started to drip off the fruit. The MeJA treatment was performed in the morning on a day without wind and precipitation. The fruits were harvested on October 22, 2010 (175 days after full blooming), and they were transferred to the laboratory in polythene bags to reduce water loss during transportation. 


\section{Plant measurements}

Physical properties. A total of 20 fruits were randomly harvested from two trees in each block for each treatment at the estimated harvest date (October 22, 2010). Twenty fruits were used to determine the physical properties (length, width, thickness, fruit mass, fruit firmness, skin thickness, and color characteristics), and the mean values were calculated. Fruit length, width, and thickness were measured with $0.01 \mathrm{~mm}$ sensitive digital calipers (Model No. CD-6CSX, Mitutoyo, Japan). The geometric mean diameter $\left(\mathrm{D}_{\mathrm{g}}\right)$ of the apple fruit was determined by a previously described standard method (Mohsenin, 1970). The measurements of fruit mass were determined with a $0.01 \mathrm{~g}$ sensitive digital scale (Radvag PS $4500 / \mathrm{C} / 1$, Poland). Fruit stalks were cut off before the measurement. The fruit skin was directly measured at three different points on the equatorial part of the fruit. Moreover, the fruit skin was cut at three different points on the equatorial part of the fruit to measure the flesh and skin firmness using an Effegi penetrometer with an $11.1 \mathrm{~mm}$ tip (model FT-327; MoCormick Fruit Tech, Yakima, WA), and the values were expressed as Newton $(\mathrm{N})$. The skin thickness was measured by using a digital micrometer (0-25 mm; Insize, Austria) with an accuracy of $0.001 \mathrm{~mm}$. The color characteristics ( $L^{*}, a^{*}, b^{*}$, chroma and hue angle) of 20 apples from each treatment were measured by using a colorimeter (Minolta, model CR-400, Tokyo, Japan). The measurements of apple skin and flesh colors were performed on the sun- and shade-exposed sides on equidistant points of the equatorial section of the apples. Measurements were obtained using the CIE L*, (light to dark), $a^{*}$ (green to red) and $b^{*}$ (blue to yellow) color spaces, and the $a^{*}$ and $b^{*}$ values were converted to hue angle and chroma. The hue angle $\left(h^{\circ}\right)$ expresses the color nuance and was calculated using the following equation: $h^{\circ}=\tan ^{-1} \mathrm{~b}^{*} / \mathrm{a}^{*}$. The hue angle values are defined as follows: red-purple, $0^{\circ}$; yellow, $90^{\circ}$; bluish-green, $180^{\circ}$; and blue, $270^{\circ}$. Chroma $\left(C^{*}\right)$ is a measure of chromaticity, which defines the purity or saturation of the color, and it was calculated with the following equation: $C^{*}=$ $\left(\mathrm{a}^{* 2}+\mathrm{b}^{* 2}\right)^{1 / 2}$ (McGuire, 1992).

Biochemical properties. Ten fruits were randomly harvested from two trees in each block for each treatment at the estimated harvest date (October 22, 2010). Ten fruits were used to determine the total soluble solids content (TSSC), $\mathrm{pH}$, titratable acidity (TA) and starch index. A sample of juice was also taken from each fruit. TSSC was measured using a digital refractometer (PAL-1; McCormick Fruit Tech., Yakima, Wash) and was expressed as a percentage. The $\mathrm{pH}$ values were measured with a pH meter (HI9321; Hanna instruments, Padova, Italy). Titratable acidity was determined by titrating to $\mathrm{pH} 8.1$ with $0.1 \mathrm{~N}$ sodium hydroxide $(\mathrm{NaOH})$ and was expressed as percent malic acid. Starch index was determined using the Generic StarchIodine Index Chart from Cornell University. Each apple fruit was cut in half transversely, and the flesh starch was then evaluated by spraying half of each apple with a test solution (10 $\mathrm{g}$ of potassium iodide and $2.5 \mathrm{~g}$ of iodine crystals dissolved in $1 \mathrm{~L}$ of water). The degree of staining was rated on a scale of 1 to 8 as follows: $1=100 \%$ starch and $8=0 \%$ starch (Blanpied and Silsby, 1992).

Ten fruits from two trees in each block for each treatment were mashed to measure the total phenolics, total antioxidant activity and total anthocyanins. Total phenolics (TPs) were measured according to the Singleton and Rossi (1965) procedure. Briefly, fruit slurries (only cortex) were extracted with a buffer containing acetone, water, and acetic acid (70:29.5:0.5 v/v) for $2 \mathrm{~h}$ in darkness. Triplicate samples were used for the measurements. Extracts were combined with Folin-Ciocalteus phenol reagent and water, and the extracts were then incubated for $8 \mathrm{~min}$ followed by the addition of $7 \%$ sodium carbonate. After $2 \mathrm{~h}$, the absorbance at $750 \mathrm{~nm}$ was measured in an automated UV-VIS spectrophotometer (Model T60U, PG Instruments, USA). Gallic acid was used as the standard. The results were expressed as mg gallic acid equivalents (GAE)/ $\mathrm{kg}$ fresh weight (fw). Total antioxidant activity 
(TAA) was estimated using the two standard procedures, FRAP and TEAC assays, as suggested by Ozgen et al. (2006). FRAP was determined according to the method of Benzie and Strain (1996). The assay was conducted using three aqueous stock solutions containing $0.1 \mathrm{~mol} \mathrm{~L}^{-1}$ acetate buffer ( $\mathrm{pH} 3.6), 10 \mathrm{mmol} \mathrm{L}^{-1}$ 2,4,6-tris(2pyridyl)-1,3,5-triazine (TPTZ) acidified with concentrated hydrochloric acid, and $20 \mathrm{mmol} \mathrm{L}^{-1}$ ferric chloride. These solutions were prepared and stored in the dark under refrigeration. Stock solutions were combined $(10: 1: 1 \mathrm{v} / \mathrm{v} / \mathrm{v})$ to form the FRAP reagent just prior to analysis. For each assay, duplicates of each replicate plus $2.90 \mathrm{~mL}$ of FRAP reagent and $100 \mu \mathrm{L}$ of sample extract were mixed. After $30 \mathrm{~min}$, the absorbance of the reaction mixture at $593 \mathrm{~nm}$ was determined using a spectrophotometer. The results were expressed in mmol Trolox equivalent (TE) $\mathrm{kg}^{-1}$ fw. For the standard TEAC assay, $10 \mathrm{mmol} \mathrm{L}^{-1}$ 2,2-azino-bis-3-ethylbenzothiazoline-6-sulfonic acid (ABTS) was dissolved in acetate buffer and prepared with potassium persulfate as described by Ozgen et al. (2006). The mixture was diluted using an acidic medium of $20 \mathrm{mM}$ sodium acetate buffer ( $\mathrm{pH} 4.5$ ) to an absorbance of $0.700 \pm 0.01$ at $734 \mathrm{~nm}$ for longer stability (Ozgen et al., 2006). For the spectrophotometric assay, $2.90 \mathrm{~mL}$ of the $\mathrm{ABTS}^{+}$solution and $100 \mu \mathrm{L}$ of fruit extract were mixed and incubated for $10 \mathrm{~min}$. The absorbance at $734 \mathrm{~nm}$ was then determined. The results were expressed in mmol trolox equivalents (TE) $\mathrm{kg}^{-1} \mathrm{fw}$. The total anthocyanins were estimated by a $\mathrm{pH}$ differential method (Giusti and Wrolstad, 2005) using a UV-VIS spectrophotometer (Model T60U, PG Instruments, USA). Absorbance was measured at 533 and $700 \mathrm{~nm}$ in buffers at $\mathrm{pH} 1.0$ and 4.5 using $\mathrm{pH} 4.5$ with a molar extinction coefficient of 29.600. Results were expressed as $\mu$ g cyanidin-3galactoside $\mathrm{g}^{-1} \mathrm{fw}$ equivalent in $\mathrm{g}$ fresh weight basis.

\section{Statistical analysis}

Experiments were performed using a completely randomized block design. All statistical analyses were performed with SAS version 9.1 software (SAS Institute Inc., Cary, NC, USA). Data were analyzed by analysis of variance. The main effects were analyzed, and means were compared by Duncan's multiple range test at a significance level of 0.05 .

\section{Results and discussion}

\section{Physical properties}

The physical properties (geometric mean diameter, fruit mass, firmness and skin thickness) of 'Fuji' apples are shown in Table 1. The effects of the MeJA treatment on the geometric mean diameter, fruit mass, skin firmness and flesh firmness of apple were not significant, but the skin thickness was affected by MeJA treatment $(\mathrm{P} \leq 0.05)$. The lowest geometric mean diameter, fruit mass, flesh firmness and skin firmness values were obtained in the MeJA-0 treatment, and the highest geometric mean diameter, fruit mass and flesh firmness values were obtained in the MeJA-2 treatment. Skin firmness values increased with increasing MeJA doses. Flesh firmness values increased in the MeJA-0, MeJA-1, and MeJA-2 treatments but decreased in the MeJA-3 treatment. The highest skin thickness $(1.02 \mathrm{~mm})$ was obtained in the MeJA-0 treatment, and the lowest skin thickness value $(0.75 \mathrm{~mm})$ was observed in the MeJA-3 treatment. The skin thickness was negatively affected by MeJA applications.

When applied to fruit in the first developmental stages, MeJA can affect cell division and growth. MeJA does not have a positive effect on fruit size when it is applied in the late developmental stages. Cell division continues for 3 or 12 weeks following flowering (Al- Hinai and Roper, 2004). Cell division varies by the length of vegetation period, climatic conditions and fruit varieties. MeJA did not have a positive effect on geometric mean diameter, fruit mass and firmness. In the present study, the basic objective to apply MeJA during the second phase of growth period 
Table 1. Physical properties of 'Fuji' apples as affected by methyl jasmonate (MeJa) treatments.

\begin{tabular}{lcccc}
\hline & \multicolumn{4}{c}{ MeJa treatments } \\
\cline { 2 - 5 } Physical properties & MeJA-0 & MeJA-1 & MeJA-2 & MeJA-3 \\
\hline Geometric mean diameter, mm & $69.5 \pm 1.63 \mathrm{a}$ & $71.4 \pm 0.42 \mathrm{a}$ & $73.0 \pm 4.45 \mathrm{a}$ & $70.0 \pm 1.96 \mathrm{a}$ \\
Fruit mass, g & $190.2 \pm 14.10 \mathrm{a}$ & $196.5 \pm 5.89 \mathrm{a}$ & $197.3 \pm 11.88 \mathrm{a}$ & $194.8 \pm 13.29 \mathrm{a}$ \\
Flesh firmness, No. & $71.0 \pm 7.45 \mathrm{a}$ & $74.21 .34 \mathrm{a}$ & $75.5 \pm 2.90 \mathrm{a}$ & $72.7 \pm 1.80 \mathrm{a}$ \\
Skin firmness, No. & $100.4 \pm 2.14 \mathrm{a}$ & $101.54 .89 \mathrm{a}$ & $104.1 \pm 1.81 \mathrm{a}$ & $112.6 \pm 5.29 \mathrm{a}$ \\
Skin thickness, mm & $1.02 \pm 0.02 \mathrm{a}$ & $0.94 \pm 0.01 \mathrm{~b}$ & $0.87 \pm 0.04 \mathrm{c}$ & $0.75 \pm 0.02 \mathrm{~d}$ \\
\hline
\end{tabular}

The following treatments were used; MeJA-0 (control), 0 mg L-1; MeJA-1, 1,120 mg L ${ }^{-1}$; MeJA-2, 2,240 $\mathrm{mg} \mathrm{L}^{-1}$; and MeJA-3, 4,480 $\mathrm{mg} \mathrm{L}^{-1}$.

The difference between mean values shown on the same line with the same lower letter is not significant $(\mathrm{P} \leq 0.05)$. Means of three replicates \pm standard deviations. Each value is the mean of 60 fruits $(20$ fruits $\mathrm{x}$ three replications).

was to determine the effects on variations in physicochemical quality, color and bioactive compounds during this period. Therefore, MeJA was not applied during the first phase of growth. The application time of MeJA (4 weeks before the estimated harvest date) may have contributed to the lack of positive effects caused by MeJA. Indeed, Rudell et al. (2005) obtained a similar result when studying 'Fuji' apples. Kheiralipour et al. (2008) reported geometric mean diameter, length, width and thickness values of 79.54, 74.78, 83.80 and $80.37 \mathrm{~mm}$, respectively, for 'Redspar' apples and $63.38,58.31,67.00$ and $65.04 \mathrm{~mm}$, respectively, for 'Delbarestivale' apples. The increase occurring in fruit firmness may have derived from different physiological processes apart from maturity level. A relation between fruit size and firmness can be established. When studying the Fuji' apple variety, Rudell et al. (2005) reported that such a relation can exist, and this indicated relationship was also observed in the present study. Janoudi and Flore (2003) reported that MeJA increases fruit firmness in 'Redhaven' peaches. In the present study, the MeJA treatments yielded higher fruit firmness than the control, which may have been due to the effect of MeJA on enzymes that cause softening of the fruit flesh. In relation to fruit firmness, Fan et al. (1998) reported that polygalacturonase biosynthesis is inhibited by MeJA treatment. Costa et al. (2008) studied 'Fuji' apples and 'Stark Red Gold' nectarines, and they reported that propyl dihydrojasmonate (PDJ) applied pre-harvest maintains fruit firmness in 'Stark Red
Gold' nectarines. In addition, Kondo et al. (2004) reported that the activity of jasmonates varies by fruit ripening stage and applied concentration. Homutova and Blazek (2006) reported that each apple variety has a different skin thickness. The skin thickness can be influenced by the year, variety, pesticide application and early-late cultivar ripening (Babos et al., 1984). In the present study, the skin thickness may have decreased with increasing MeJA doses.

The skin and flesh color characteristics ( $\mathrm{L}^{*}$, chroma, and hue angle) of apples are shown in Table 2. The highest and lowest $\mathrm{L}^{*}$ values $(53.50$ and 48.61, respectively) were in the MeJA-0 and MeJA-2 treatments, respectively, and the highest and lowest chroma vales (37.95 and 35.97, respectively) were in the MeJA-3 and MeJA-0 treatments, respectively, for the sun-exposed side of the apple skin. The chroma and hue angle values of the apple flesh increased with increasing MeJa treatments for both the sun- and shade-exposed sides. The effects of MeJa treatments on color characteristics were statistically significantly $(\mathrm{P} \leq 0.05)$ for the sun- and shade-exposed sides of the apple skin and flesh.

MeJA promotes the formation of color pigments, which enhance fruit skin color (Lalel et al., 2003; Rudell et al., 2005). The present study indicated that MeJA treatments particularly promoted red color development. Kondo et al. (2001) reported that MeJa treatments promoted not only 
Table 2. Effect of methyl jasmonate (MeJa) treatments on the color properties of 'Fuji' apples.

\begin{tabular}{lcccc}
\hline & \multicolumn{4}{c}{ MeJa treatments } \\
\cline { 2 - 5 } Color properties & MeJA-0 & MeJA-1 & MeJA-2 & MeJA-3 \\
\hline Sun-exposed side (skin) & $53.5 \pm 0.76$ ) a & $50.76 \pm 1.56 \mathrm{~b}$ & $48.61 \pm 2.86 \mathrm{ab}$ & $48.890 .76 \mathrm{ab}$ \\
$\mathrm{L}^{*}$ & $35.97 \pm 1.92 \mathrm{a}$ & $37.67 \pm 2.08 \mathrm{a}$ & $36.57 \pm 0.40 \mathrm{a}$ & $37.95 \pm 1.92 \mathrm{a}$ \\
Chroma & $47.85 \pm 3.95 \mathrm{a}$ & $41.58 \pm 1.54 \mathrm{~b}$ & $40.95 \pm 4.93 \mathrm{~b}$ & $36.69 \pm 3.95 \mathrm{~b}$ \\
Hue angle & & & & \\
Shade-exposed side (skin) & $64.77 \pm 1.69 \mathrm{a}$ & $64.58 \pm 1.18 \mathrm{a}$ & $59.12 \pm 0.42 \mathrm{~b}$ & $60.65 \pm 1.69 \mathrm{~b}$ \\
L* & $35.01 \pm 1.82 \mathrm{a}$ & $36.08 \pm 1.51 \mathrm{a}$ & $34.91 \pm 0.86 \mathrm{a}$ & $36.10 \pm 1.82 \mathrm{a}$ \\
Chroma & $77.77 \pm 2.53 \mathrm{a}$ & $72.80 \pm 4.28 \mathrm{ab}$ & $67.00 \pm 3.20 \mathrm{~b}$ & $65.122 .53 \mathrm{~b}$ \\
Hue angle & & & & \\
Sun-exposed side (flesh) & $83.02 \pm 1.30 \mathrm{a}$ & $79.20 \pm 1.85 \mathrm{a}$ & $82.78 \pm 0.15 \mathrm{a}$ & $83.40 \pm 1.30 \mathrm{a}$ \\
L* & $37.88 \pm 4.00 \mathrm{ab}$ & $33.44 \pm 1.67 \mathrm{~b}$ & $36.72 \pm 0.64 \mathrm{ab}$ & $38.974 .00 \mathrm{a}$ \\
Chroma & $101.75 \pm 2.73 \mathrm{a}$ & $98.50 \pm 0.66 \mathrm{ab}$ & $101.44 \pm 3.08 \mathrm{a}$ & $96.432 .34 \mathrm{~b}$ \\
Hue angle & & & & \\
Shade-exposed side (flesh) & & & & \\
L* & $81.58 \pm 0.23 \mathrm{~b}$ & $79.95 \pm 1.32 \mathrm{c}$ & $82.15 \pm 0.57 \mathrm{ab}$ & $83.57 \pm 0.23 \mathrm{a}$ \\
Chroma & $33.55 \pm 3.72 \mathrm{~b}$ & $31.65 \pm 1.38 \mathrm{~b}$ & $37.26 \pm 4.02 \mathrm{ab}$ & $41.26 \pm 3.72 \mathrm{a}$ \\
Hue angle & $102.03 \pm 1.38 \mathrm{a}$ & $99.34 \pm 0.62 \mathrm{~b}$ & $101.15 \pm 1.63 \mathrm{ab}$ & $96.94 \pm 1.38 \mathrm{c}$ \\
\hline
\end{tabular}

The following treatments were used: MeJA-0 (control), $0 \mathrm{mg} \mathrm{L}^{-1}$; MeJA-1, 1,120 mg L-1; MeJA-2, 2,240 $\mathrm{mg} \mathrm{L}^{-1}$; and MeJA-3, 4,480 $\mathrm{mg} \mathrm{L}^{-1}$.

The difference between mean values shown on the same line with same lower letter is not significant $(\mathrm{P} \leq 0.05)$. Means of three replicates \pm standard deviations. Each value is mean of 60 fruits $(20$ fruits $\mathrm{x}$ three replications).

chlorophyll disappearance but also anthocyanin accumulation. Plant growth regulators can improve fruit coloration (Kondo and Hayata, 1995). Hue angle values approaching zero in fruits with red skin color indicate an increase in red coloration (Diaz-Mula et al., 2009). MeJA stimulates ethylene release based on growth stages of fruits, speeds up ripening, speeds up chlorophyll breakup and increases carotenoid accumulation (GonzalezAguilar et al., 2003; Lalel et al., 2003; Y1lmaz et al., 2007). Kondo et al. (2001) reported that MeJA promotes color pigments in apples during the pre-climacteric, climacteric and post-climacteric developmental stages.

\section{Biochemical properties}

The chemical properties of 'Fuji' apples are presented in Table 3. The lowest TSSC and $\mathrm{pH}$ values were obtained in the MeJA- 3 treatment (12.88\% and 3.03, respectively), and the highest
TSSC and $\mathrm{pH}$ values were obtained in the MeJA0 treatment ( $14.0 \%$ and 3.14 , respectively). The $\mathrm{pH}$ value was significantly different between the MeJA-3 and MeJA-0 treatments. While the lowest titratable acidity (TA) and starch index values were obtained in the MeJA- 0 treatment $(0.40 \mathrm{~g}$ malic acid $100 \mathrm{~g} \mathrm{~g}^{-1}$ and 5, respectively), the highest TA and starch index values were obtained in the MeJA-3 treatment $\left(0.55 \mathrm{~g}\right.$ malic acid $100 \mathrm{~g}^{-1}$ and 7 , respectively).

As fruit maturity increases, TSSC also increases (Turk et al., 1995). Fruit sugar content and, consequently, acidity increase with the progress of ripening. Whale et al. (2008) reported TSSC and TA values of 13.3 and $0.78 \%$ malic acid, respectively, for apples (cv. Cripp's Pink), which were similar to the values obtained in the present study. Fan et al. (1997) and Khan and Singh (2007) reported that the chemical content of fruit can change due to MeJA application. 
Table 3. Biochemical properties of 'Fuji' apples as affected by methyl jasmonate (MeJa) treatments.

\begin{tabular}{|c|c|c|c|c|}
\hline \multirow[b]{2}{*}{ Biochemical properties } & \multicolumn{4}{|c|}{ MeJa treatments } \\
\hline & MeJA-0 & MeJA-1 & MeJA-2 & MeJA-3 \\
\hline $\operatorname{TSSC}(\%)$ & $14.00 \pm 0.61 \mathrm{a}$ & $13.05 \pm 0.66 \mathrm{a}$ & $12.95 \pm 0.73 \mathrm{a}$ & $12.880 .61 \mathrm{a}$ \\
\hline $\mathrm{pH}$ & $3.14 \pm 0.08 \mathrm{a}$ & $3.10 \pm 0.05 \mathrm{ab}$ & $3.07 \pm 0.03 \mathrm{ab}$ & $3.03 \pm 0.08 \mathrm{~b}$ \\
\hline TA (g malic acid $\left.100 \mathrm{~g}^{-1}\right)$ & $0.40 \pm 0.02 \mathrm{c}$ & $0.44 \pm 0.01 \mathrm{~b}$ & $0.48 \pm 0.04 \mathrm{~b}$ & $0.55 \pm 0.02 \mathrm{a}$ \\
\hline Starch index & $5 \pm 0.76 \mathrm{~b}$ & $6.00 \pm 0.58 \mathrm{a}$ & $6.00 \pm 0.58 \mathrm{a}$ & $7.00 \pm 0.76 \mathrm{a}$ \\
\hline \multicolumn{5}{|c|}{ 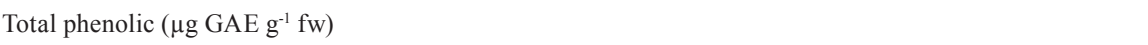 } \\
\hline Fruit flesh & $861.5 \pm 103.6 \mathrm{ab}$ & $908.7 \pm 193.8 \mathrm{a}$ & $664.3 \pm 129.7 \mathrm{bc}$ & $494.9 \pm 96.14 \mathrm{c}$ \\
\hline Skin fruit & $7940 \pm 990.6 \mathrm{a}$ & $7385548.1 \mathrm{a}$ & $5599 \pm 227.0 \mathrm{~b}$ & $7724 \pm 792.6 \mathrm{a}$ \\
\hline \multicolumn{5}{|c|}{ Total antioxidant activity $\left(\mu \mathrm{mol} \mathrm{TE} \mathrm{g}^{-1} \mathrm{fw}\right)$} \\
\hline \multicolumn{5}{|l|}{ FRAP } \\
\hline Fruit flesh & $0.78 \pm 0.06 \mathrm{ab}$ & $0.80 \pm 0.08 \mathrm{a}$ & $0.66 \pm 0.03 \mathrm{c}$ & $0.71 \pm 0.04 \mathrm{bc}$ \\
\hline Fruit skin & $8.16 \pm 1.35 \mathrm{a}$ & $5.97 \pm 0.30 \mathrm{~b}$ & $4.43 \pm 0.37 \mathrm{c}$ & $7.34 \pm 0.26 \mathrm{a}$ \\
\hline \multicolumn{5}{|l|}{ TEAC } \\
\hline Fruit flesh & $0.69 \pm 0.02 \mathrm{a}$ & $0.71 \pm 0.21 \mathrm{a}$ & $0.51 \pm 0.02 \mathrm{~b}$ & $0.63 \pm 0.06 \mathrm{ab}$ \\
\hline Fruit skin & $6.90 \pm 0.55 \mathrm{a}$ & $6.370 .47 \mathrm{a}$ & $3.71 \pm 0.23 \mathrm{~b}$ & $6.56 \pm 0.39$ a \\
\hline \multicolumn{5}{|c|}{ Total anthocyanins ( $\mu$ g cyanidin-3-galactoside $\mathrm{g}^{-1} \mathrm{fw}$ ) } \\
\hline & $3.79 \pm 1.90 \mathrm{c}$ & $6.04 \pm 1.60 \mathrm{bc}$ & $8.68 \pm 0.91 \mathrm{ab}$ & $9.26 \pm 1.39 \mathrm{a}$ \\
\hline
\end{tabular}

The following treatments were used: MeJA-0 (control), $0 \mathrm{mg} \mathrm{L}^{-1}$; MeJA-1, 1,120 mg L-1; MeJA-2, 2,240 $\mathrm{mg} \mathrm{L}^{-1}$; and MeJA-3, 4,480 $\mathrm{mg} \mathrm{L}^{-1}$.

The difference between mean values shown on the same line with the same lower letter is not significant $(\mathrm{P} \leq 0.05)$. Means of three replicates \pm standard deviations. TSSC, $\mathrm{pH}, \mathrm{TA}, \mathrm{TP}, \mathrm{TAA}$ and total anthocyanins $(n=12$; three replications $x$ four different measurement for each replicate). Starch index $(n=30$; ten fruits $\mathrm{x}$ three replications).

While the MeJA-0 and MeJA-1 treatments were similar in terms of fruit flesh TP values, these treatments differed from the MeJA-3 treatment in terms of these values. While the lowest fruit flesh TP value was obtained in the MeJA-3 treatment (494.9 $\mu \mathrm{g} \mathrm{GAE} \mathrm{g}^{-1} \mathrm{fw}$ ), the highest fruit flesh TP value was obtained in the MeJA-1 treatment $\left(908.7 \mu \mathrm{g} \mathrm{GAE} \mathrm{g}^{-1} \mathrm{fw}\right)$. The fruit skin TP value significantly decreased with MeJA-2 treatment. According to the FRAP test, the lowest fruit flesh TAA value was obtained in the MeJA-2 treatment $\left(0.66 \mu \mathrm{mol} \mathrm{g}^{-1} \mathrm{fw}\right)$. In contrast, the highest fruit flesh TAA value was obtained in the MeJA-1 treatment $\left(0.80 \mu \mathrm{mol} \mathrm{TE} \mathrm{g}^{-1} \mathrm{fw}\right)$. A statistical difference was found among the treatments in terms of fruit skin TAA values. While the MeJA-0 and MeJA-3 treatments were similar in terms of fruit skin TAA values, the MeJA-1 and MeJA-2 treatments were found to be statistically different. According to the TEAC test, the highest fruit flesh TAA value was obtained in the MeJA-1 treatment $\left(0.71 \mu \mathrm{mol} \mathrm{TE} \mathrm{g}^{-1} \mathrm{fw}\right)$, and the lowest fruit flesh TAA value was obtained in the MeJA-2 treatment $\left(0.51 \mu \mathrm{mol} \mathrm{TE} \mathrm{g}^{-1} \mathrm{fw}\right)$. The MeJA-0, MeJA-1 and MeJA-3 treatments were statistically similar in terms of fruit flesh TAA values, and the MeJA-2 treatment was statistically different from the other treatments with regard to fruit flesh TAA values. The highest fruit skin TAA value $(6.90 \mu \mathrm{mol} \mathrm{TE}$ $\left.\mathrm{g}^{-1} \mathrm{fw}\right)$ was obtained in the MeJA- 0 treatment, and the lowest fruit skin TAA value $(3.71 \mu \mathrm{mol}$ $\mathrm{TE} \mathrm{g}^{-1} \mathrm{fw}$ ) was obtained in the MeJA-2 treatment. The total anthocyanins linearly increased with increasing MeJA doses. The lowest and highest total anthocyanin contents were obtained in the MeJA-0 (3.79 $\mu$ g cyaniding-3-galactoside $\left.\mathrm{g}^{-1} \mathrm{fw}\right)$ and MeJA-3 (9.26 $\mu$ g cyaniding-3-galactoside $\mathrm{g}^{-1}$ fw) treatments, respectively.

The composition of phenolics, antioxidants and anthocyanins of fruits are affected by preharvest MeJA treatments (Kim et al., 2003). 
The exogenous application of MeJA treatments affects the ripening parameters, including ethylene production, aroma development, and pigment changes (anthocyanins, chlorophyll and carotenoid), of apple fruit. Moreover, the anthocyanin accumulation, phenolic contents and antioxidant contents of apple fruit are enhanced with MeJA treatments (Wang and Zheng, 2005; Rohwer and Erwin, 2008). Wang and Zheng (2005) reported that the phenolic concentration of fruit increases with pre-harvest MeJA treatment in apples. The anthocyanin content and color development increased during maturation until the commercial harvest date. Pre-harvest MeJA treatment promotes anthocyanin accumulation (Fan et al., 1997). Anthocyanin accumulation increases sales appeal, market value and bioactive quality of apples. Consumers will benefit the most by eating apples with peels. Similar increasing anthocyanin trends of apples have been reported by Fan et al. (1997). Wojdylo et al. (2008) reported total antioxidant activity values of 80.9, 199.1, 88.6, and $181.9 \mu \mathrm{M} \mathrm{g}^{-1}$ according to an $\mathrm{ABTS}^{+}$ test and values of $23.4,29.7,23.2$, and $26.4 \mu \mathrm{M}$ $\mathrm{g}^{-1}$ according to a FRAP test.
Significant effects of MeJA treatments were not observed on the geometric mean diameter, fruit mass, flesh firmness and skin firmness. However, the skin thickness was lower in the MeJA treatments than in the control treatments. The hue angle values were significantly different in the MeJA-2 and MeJA-3 treatments as compared to the other treatments for the sun- and shadeexposed sides of apple skin, and the hue angle value was significantly different in the MeJA-3 treatment as compared to the other treatments for the sun- and shade-exposed sides of apple flesh. The TSSC and $\mathrm{pH}$ values decreased linearly with increasing MeJA doses, but the titratable acidity significantly increased with increasing MeJA doses. In general, the antioxidant and phenolic contents of fruit flesh in the present study were negatively affected by increasing MeJA doses. However, the fruit skin total anthocyanins significantly increased with increasing MeJA doses. Therefore, these data suggest that apples should be consumed with their skin because anthocyanins have the greatest contribution to the nutritional value of apples.

\section{Resumen}

B. Öztürk, E. Altuntas, K. Yildiz, Y. Ozkan y O. Saracoglu. 2013. Efecto de los tratamientos de metilo jasmonato, en compuestos bioactivos y calidades físico-químicas de la manzana 'Fuji'. Cien. Inv. Agr. 40(1):201-211. Recientemente, los reguladores del crecimiento de plantas se han utilizado para múltiples propósitos en las manzanas. Metil jasmonato (MeJA) afecta de manera importante la fisiología, la biología después de la cosecha, procesamiento y contenido químico de la manzana. En este estudio se investigó el efecto de los tratamientos de metilo jasmonato en calidades fitoquímicas y compuestos bioactivos (actividad antioxidante total, fenoles totales, antocianos totales) de la manzana 'Fuji'. Las dosis de metil jasmonato utilizadas fueron: 1120, 2240 y $4480 \mathrm{mg} \mathrm{L}^{-1}$. El mayor diámetro medio geométrico, masa del fruto, firmeza de la pulpa y el grosor de la piel se obtuvo a partir de tratamiento de MeJA $2240 \mathrm{mg} \mathrm{L}^{-1}$. Las frutas recolectadas de árboles del tratamiento control exhibieron el más alto contenido de sólidos solubles totales (TSSC) y el $\mathrm{pH}$, mientras que la menor TSSC y $\mathrm{pH}$ se obtuvo del tratamiento de MeJA $4480 \mathrm{mg} \mathrm{L}^{-1}$. La acidez titulable fue menor en el control, en comparación con los otros tratamientos. Los fenoles totales de la pulpa del fruto disminuyeron con el aumento de dosis metil jasmonato. La mayor actividad antioxidante total, tanto de FRAP y TEAC de pulpa de la fruta se obtuvo de la dosis de MeJA $1120 \mathrm{mg} \mathrm{L}^{-1}$. La antocianina total fue mayor en la dosis de MeJA $4480 \mathrm{mg}$ $\mathrm{L}^{-1}$, respecto a los otros tratamientos. Ángulos de tono para la piel expuesta al sol y sombra y 
la pulpa de la fruta, fueron menores en la dosis de MeJA $4480 \mathrm{mg} \mathrm{L}^{-1}$, en comparación a los otros tratamientos. Las manzanas sin formación de color se venden a precios más bajos en los mercados, y por consiguiente, importantes pérdidas económicas para los productores. MeJA puede ser utilizado como una herramienta eficaz para promover la formación de color de las especies de manzanas que por condiciones genéticas y clima, poseen un color débil.

Palabras clave: Antioxidante, color, compuestos fenólicos, firmeza, manzana, metil jasmonato.

\section{References}

Al-Hinai, Y.K., and T.R. Roper. 2004. Rootstock effects on growth, cell number, and cell size of 'Gala' apples. Journal of the American Society for Horticultural Science 123:37-41.

Babos, K., P. Sass, and P. Mohacsy. 1984. Relationship between the peel structure and storability of apples. Acta Agronomica Academiae ScientiarumHungaricae 33:41-50.

Benzie, I.F.F., and J.J. Strain. 1996. The ferric reducing ability of plasma (FRAP) as a measure of "antioxidant power": the FRAP assay. Analytical Biochemistry 239:70-76.

Blanpied, W.J., and K.J. Silsby. 1992. Predicting harvest date Windows for apples. Cornell Cooperative Extension Information Bulletin 221.

Cheong, J.J., and Y.D. Choi. 2003. Methyl jasmonate as a vital substance in plants. Trends in Genetics 19:409-413.

Costa, G., F. Costa, and A.M. Bregoli. 2008. Effect of exogenous application of jasmonates and 1- methylcyclopropene (1-MCP) for pre- and postharvest control of peach and apple fruit ripening. In: Webster, A.D., and J.M. Lee (eds.). Proceedings of the XXVII International Horticultural Congress-S9, Endogenous and Exogenous Plant Bioregulators. Acta Horticulturae 774:179-185.

Diaz-Mula, H.M., P.J. Zapata, F. Guillen, D. MartinezRomero, S. Castillo, M. Serrano, and D. Valero. 2009. Changes in hydrophilic and lipophilic antioxidant activity and related bioactive compounds during postharvest storage of yellow and purple plum cultivars. Postharvest Biology and Technology 51:354-363.
Fan, X., J.P. Mattheis, J.K. Fellman, and M.E. Patterson. 1997. Effect of methyl jasmonate on ethylene and volatile production by summerred apples depends on fruit developmental stage. Journal of Agricultural and Food Chemistry 45:208-211.

Fan, X., J.P. Mattheis, and J.K. Fellman. 1998. Responses of apples to postharvest jasmonate treatments. Journal of the American Society for Horticultural Science 123:421-425.

Giusti, M.M., and R.E. Wrolstad. 2005. Characterization and measurement of anthocyanins by UV-visible spectroscopy Unit F1.2. In: Wrolstad, R.E., Schwartz, S.J. (eds.). Handbook of Food Analytical Chemistry. Wiley, New York. p. 19-31.

Gonzalez-Aguilar, G.A., J.G. Buta, and C.Y. Wang. 2003. Methyl jasmonate and modified atmosphere packaging (MAP) reduce decay and maintain postharvest quality of papaya 'Sunrise'. Postharvest Biology and Technology 28:361-370.

Gonzalez-Gomez, D., M. Lozano, M.F. FernandezLeon, M.J. Bernalte, M.C. Ayuso, and A.B. Rodriguez. 2009. Sweet cherry phytochemicals: identification and characterization by HPLCDAD/ESI-MS in six sweet cherry cultivars grown in Valle del Jerte (Spain). Journal of Food Composition and Analysis 23:533-539.

Heridia, J.B., and L. Cisneros-Zevallos. 2009. The effects exogenous ethylene and methyl jasmonate on the accumulation of phenolic antioxidant in selected whole and wounded fresh produce. Food Chemistry 115:1500-1508.

Homutova, I., and J. Blazek. 2006. Differences in fruit skin thickness between selected apple (Malus domestica) cultivars assessed by histological 
and sensory methods. Horticultural Science 33:108-113.

Jakopic, J., F. Stampar, and R. Veberic. 2009. The influence of exposure to light on the phenolic content of Fuji apple. Scientia Horticulturae 123:234-239.

Janoudi, A., and J.A. Flore. 2003. Effects of multiple applications of methyl jasmonate on fruit ripening, leaf gas exchange and vegetative growth in fruit trees. Journal of Horticultural Science and Biotechnology 78:793-797.

Khan, A.S., and Z. Singh. 2007. Methyl jasmonate promotes fruit ripening and improves fruit quality in Japanese plum. Journal of Horticultural Science and Biotechnology 82:695-706.

Kheiralipour, K., A. Tabatabaeefar, H. Mobli, S. Rafiee, M. Sharifi, A. Jafari, and A. Rajabipour. 2008. Some physical and hydrodynamic properties of two varieties of apple (Malus domestica Borkh L.). International Agrophysics 22:225-229.

Kim, D.O., O.K. Chun, Y.J. Kim, H.Y. Moon, and C.Y. Lee. 2003. Quantification of polyphenolics and their antioxidant capacity of fresh plums. Journal of Agricultural and Food Chemistry 51:6509-6515.

Kondo, S., and Y. Hayata. 1995. Effects of AVG and 2,4-DP on preharvest drop and fruit quality of'Tsugaru' apples. Journal of Japanese Society for Horticultural Science 64:275-281.

Kondo, S., N. Tsukada, Y. Niimi, and H. Seto. 2001. Interactions between jasmonates and abscisic acid in apple fruit, and stimulative effect of jasmonates on anthocyanin accumulation. Journal of Japanese Society for Horticultural Science 70:546-552.

Kondo, S., F. Yazama, K. Sungcome, S. Kanlayanarat, and H. Seto. 2004. Changes in jasmonates of mangoes during development and storage after varying harvest times. Journal of the American Society for Horticultural Science 129:152-157.

Lalel, H.J.D., Z. Singh, and S.C. Tan. 2003. The role of methyl jasmonate in mango ripening and biosynthesis of aroma volatile compounds. Journal of Horticultural Science and Biotechnology 78:470-484.

McGuire, R.G. 1992. Reporting of objective color measurements. Hortscience 27:1254-1255.
Mohsenin, N.N. 1970. Physical properties of plant and animal materials. New York: Gordon and Breach Science Publishers, NY. vol. I. 734 pp.

Ozgen, M., R.N. Reese, A.Z. Tulio, A.R. Miller, and J.C. Scheerens. 2006. Modified 2,2- azino-bis3-ethylbenzothiazoline-6-sulfonic acid (ABTS) method to measure antioxidant capacity of selected small fruits and comparison to ferric reducing antioxidant power (FRAP) and 2,20-diphenyl1-picrylhydrazyl (DPPH) methods. Journal of Agricultural and Food Chemistry 54:1151-1157.

Rohwer, C.L., and J.E. Erwin. 2008. Horticultural applications of jasmonates: A review. Journal of Horticultural Science and Biotechnolgy 83:283-304.

Rudell, D.R., J.P. Mattheis, X. Fan, and J.K. Fellman, 2002. Methyl jasmonate enhances anthocyanin accumulation and modifies production of phenolics and pigments in 'Fuji' apples. Journal of the American Society for Horticultural Science 127:435-441.

Rudell, D.R., J.K. Fellman, and J.P. Mattheis. 2005. Preharvest application of methyl jasmonate to Fuji apples enhances red coloration and affects fruit size, splitting and bitter pit incidence. Hortscience 40:1760-1762.

Rudell, D.R., and J.P. Mattheis. 2008. Synergism exists between ethylene and methyl jasmonate in artifical light-induced pigment enhancement of Fuji apple fruit peel. Postharvest Biology and Technology 47:136-140.

Singleton, V.L., and J.L. Rossi. 1965. Colorimetry of total phenolics with phosphomolybdicphosphotungstic acid reagents. American Journal of Enology and Viticulture 16:144-158.

Turk, R., K. Kocak, and B. Akbudak. 1995. A research on the effect of modified atmosphere (MA) on the storage period in plums. Turkey II National Horticulture Crops Congress (3-6 October 1995), Adana, Turkey.

Wang, S.Y., and W. Zheng. 2005. Preharvest application of methyl jasmonate increases fruit quality and antioxidant capacity in raspberries. International Journal of Food Science and Technology 40:187-195. 
Whale, S.K., Z. Singh, M.H. Behboudian, J. Janes, and S.S. Dhaliwal. 2008. Fruit quality in 'Cripp's Pink' apple, especially color, as affected by preharvest sprays of aminoethoxyvinylglycine and ethephon. Scientia Horticulturae 115:342-351.

Wojdylo, A., S.J. Oszmian, and P. Laskowski. 2008. Polyphenolic compounds and antioxidant activity of new and old apple varieties. Journal of Agricultural and Food Chemistry 56:6520-6530. Yilmaz, H., K. Yildız, and F. Muradoglu. 2007. Effect of jasmonic acid on yield and quality of two strawberry cultivars. Journal of the American Pomological Society 57:32-35. 
